\title{
ANALISIS EFISIENSI ALOKATIF USAHATANI CABAI MERAH BESAR DI DESA SUKALAKSANA KECAMATAN BANYURESMI KABUPATEN GARUT
}

\author{
ALLOCATIVE EFFICIENCY ANALYSIS OF RED CHILI FARMING IN \\ SUKALAKSANA VILLAGE BANYURESMI DISTRICT GARUT REGENCY
}

\author{
Tina Sonia*1, Tuti Karyani ${ }^{1}$, Agus Susanto ${ }^{2}$ \\ ${ }^{1}$ Program Studi Agribisnis Fakultas Pertanian Universitas Padjadjaran, Sumedang \\ ${ }^{2}$ Program Studi Agroteknologi Fakultas Pertanian Universitas Padjadjaran, Sumedang \\ *E-mail: tinasonia11@gmail.com
}

(Diterima 24-08-2019; Disetujui 30-10-2019)

\begin{abstract}
ABSTRAK
Sebagian besar petani di Desa Sukalaksana Kecamatan Banyuresmi merupakan petani cabai merah besar, namun produksi cabai merah besar di Desa Sukalaksana belum optimal sehingga produktivitasnya paling rendah dibandingkan desa lainnya. Produksi dipengaruhi oleh penggunaan faktor produksi sehingga diperlukan kombinasi faktor produksi yang tepat untuk dapat menghasilkan produksi yang optimal dan efisien secara ekonomi. Tujuan penelitian ini adalah mengidentifikasi faktor-faktor produksi yang mempengaruhi produksi dan menganalisis efisiensi alokatif penggunaan faktor produksi pada usahatani cabai merah besar di Desa Sukalaksana. Metode penelitian yang digunakan adalah metode survei dengan teknik analisis menggunakan model fungsi produksi Cobb Douglas. Hasil penelitian menunjukkan bahwa penggunaan tenaga kerja, benih, pupuk kandang, pupuk kimia, dan pestisida secara bersama-sama berpengaruh terhadap produksi cabai merah besar di Desa Sukalaksana dengan nilai koefisien determinasi sebesar 85,3 persen. Adapun faktor produksi yang secara parsial berpengaruh signifikan terhadap produksi cabai merah besar adalah tenaga kerja, benih, dan pupuk kimia. Berdasarkan analisis efisiensi alokatif, penggunaan tenaga kerja dan benih belum efisien sehingga perlu ditambah, sedangkan penggunaan pupuk kimia tidak efisien sehingga perlu dikurangi.
\end{abstract}

Kata kunci: Efisiensi Alokatif, Faktor-faktor Produksi, Usahatani Cabai Merah Besar

\section{ABSTRACT}

Most of farmers in Sukalaksana Village Banyuresmi District are red chili farmers, but their red chili production has not been optimal so that the productivity of red chili in Sukalaksana is the lowest compared to other village. Production is influenced by production factors, the right combination of production factors is needed to produce optimal and economically efficient production. The purpose of this study is to identify the factors that influence production and analyze allocative efficiency of production factors in red chili farming in Sukalaksana Village. The research method used was a survey method with analytical techniques using the Cobb Douglas production function model. The results showed that labor, seeds, manure, NPK fertilizer, and pesticides simultaneously influenced the production of red chili in Sukalaksana Village with 85.3 percent determination coefficient. Production factors that partially have a significant effect on red chili production in Sukalaksana Village are labor, seeds, and NPK fertilizer. Based on allocative efficiency analysis, labor and seeds has not been efficient so its needs to be added, NPK fertilizer is not efficient so its needs to be reduced.

Keywords: Allocative Efficiency, Red Chili Farming, Production Factors 


\section{PENDAHULUAN}

Cabai merupakan salah satu komoditas sayuran semusim unggulan yang sering menjadi perhatian pemerintah dan pelaku usaha karena memiliki nilai ekonomi yang tinggi. Produksi cabai merah besar nasional dari tahun 2013 sampai tahun 2017 telah meningkat sebesar 20\%. Pada tahun 2017 produksi cabai merah besar nasional pada mencapai 1,21 juta ton. Peningkatan produksi cabai merah besar di Indonesia berbanding lurus dengan luas panennya, semakin luas area penanaman cabai maka produksi semakin besar. Pada tahun 2017, luas panen cabai merah besar mengalami peningkatan yang signifikan hingga mencapai 15,51\%. Adanya peningkatan produksi dan luas panen cabai merah besar yang signifikan pada tahun 2017 menunjukkan bahwa cabai merah besar semakin prospektif untuk dibudidayakan. Data produksi dan luas panen cabai merah besar nasional tahun 2013-2017 dapat dilihat dalam Tabel 1.

Tabel 1. Produksi dan Luas Panen Cabai Merah Besar Nasional Tahun 2013-2017

\begin{tabular}{ccc} 
Tahun & Produksi (Ton) & Luas Panen (Ha) \\
\hline 2013 & 1.012 .879 & 124.110 \\
2014 & 1.074 .602 & 128.734 \\
2015 & 1.045 .182 & 120.847 \\
2016 & 1.045 .587 & 123.404 \\
2017 & 1.206 .266 & 142.547 \\
\hline \multicolumn{2}{l}{ Sumber : Dirjen Hortikultura, (2018) }
\end{tabular}

Ditinjau dari sisi produktivitas, pola perkembangan produktivitas cabai merah besar nasional selama lima tahun terakhir mengalami fluktuasi yang cenderung menurun. Berdasarkan Gambar 1, sepanjang tahun 2013 sampai tahun 2015 produktivitas cabai merah besar terus meningkat dengan pertumbuhan sebesar $6 \%$. Produktivitas tertinggi tercapai pada tahun 2015 yaitu sebesar 8,65 ton/ha. Setelah itu produktivitas mengalami penurunan hingga tahun 2017. Produktivitas cabai merah besar yang berfluktuasi dapat disebabkan oleh kendala-kendala yang dihadapi pada proses produksi, salah satunya adalah penggunaan input produksi yang belum tepat jumlah dan kombinasinya sehingga produksi belum mampu mencapai titik optimum.

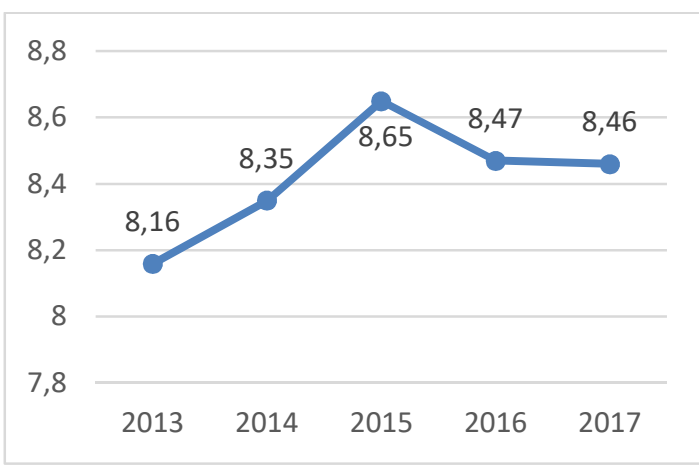

\section{Gambar 1. Perkembangan Produktivitas Cabai Merah Besar Tahun 2013-2017}

Provinsi dengan hasil produksi cabai merah besar tertinggi pada tahun 2017 adalah Provinsi Jawa Barat yang berkontribusi sebesar $22,74 \%$ dari total 
produksi cabai merah besar nasional. Kabupaten Garut merupakan daerah dengan produksi dan luas lahan cabai merah besar tertinggi di Jawa Barat. Pada tahun 2017, Kabupaten Garut menyumbang sebesar $37,3 \%$ produksi cabai merah besar Jawa Barat sehingga Garut menjadi sentra produksi cabai merah besar di Jawa Barat. Kabupaten Garut memiliki 42 Kecamatan yang sebagian besar penduduknya menanam cabai merah besar, salah satunya adalah Kecamatan Banyuresmi.

Desa Sukalaksana merupakan salah satu desa di Kecamatan Banyuresmi yang memiliki potensi pengembangan komoditas cabai merah besar karena memiliki luas lahan yang cukup besar, yaitu 163 ha. Area penanaman cabai yang luas tersebut belum dioptimalkan karena produksi dan produktivitas cabai merah besar di Desa Sukalaksana masih tergolong rendah. Produksi cabai merah besar di Desa Sukalaksana tahun 2017 sebesar 2000 ton dan produktivitasnya sebesar 12 ton/ha, sedangkan rata-rata produksi cabai merah besar di Banyuresmi tahun 2017 sebesar 3850 ton dengan rata-rata produktivitas sebesar 32 ton/ha. Hal tersebut menunjukkan bahwa produksi dan produktivitas cabai merah besar di Desa Sukalaksana berada jauh di bawah produksi dan produktivitas ratarata daerah sentra produksi, sehingga perlu dilakukan peningkatan produksi.

Produksi suatu usahatani erat kaitannya dengan penggunaan faktor produksi, seperti yang dikemukakan oleh Soekartawi (1995) bahwa produk-produk pertanian dihasilkan dari kombinasi faktor produksi berupa lahan, tenaga kerja, modal (pupuk, benih, dan obatobatan). Rahayu dan Erlyna (2010) menyatakan bahwa dalam pembangunan pertanian, teknologi penggunaan faktorfaktor produksi memegang peranan penting karena kurang tepatnya jumlah dan kombinasi faktor produksi mengakibatkan rendahnya produksi yang dihasilkan atau tingginya biaya produksi. Menurut Tuti Karyani (2015) biaya produksi cabai merah per Ha mencapai Rp. 60.000.000. Rendahnya produksi dan tingginya biaya pada akhirnya akan mengakibatkan rendahnya pendapatan petani. Oleh karena itu diperlukan efisiensi dalam penggunaan faktor produksi agar usahatani dapat menghasilkan produksi yang optimal dan efisien secara ekonomi.

Berdasarkan latar belakang yang telah diuraikan maka tujuan penelitian ini adalah: 1) Untuk mengetahui faktor produksi apa saja yang berpengaruh 
terhadap produksi cabai merah besar di Desa Sukalaksana, dan 2) Untuk menganalisis efisiensi penggunaan faktor produksi usahatani cabai merah besar di Desa Sukalaksana menggunakan pendekatan efisiensi alokatif.

\section{METODE PENELITIAN}

Penelitian ini menggunakan desain kuantitatif dengan metode survei. Lokasi penelitian di Desa Sukalaksana, Kecamatan Banyuresmi, Kabupaten Garut. Penelitian dilaksanakan pada bulan Januari sampai April 2019 pada musim tanam 2018/2019. Sampel dalam penelitian ini berjumlah 40 orang yang dipilih melalui metode simple random sampling dimana penentuan jumlah sampel tersebut mengikuti pendapat Roscoe (1975) dalam Mustofa (2000) yang menyatakan bahwa sebaiknya ukuran sampel diantara 30 sampai 500 elemen. Metode pengumpulan data dilakukan melalui wawancara dengan kuesioner.

Faktor produksi yang digunakan dalam usahatani cabai merah besar di Desa Sukalaksana adalah tenaga kerja, benih, pupuk kandang, pupuk kimia, dan pestisida. Fungsi produksi usahatani cabai merah besar diestimasi dengan menggunakan model fungsi produksi
Cobb Douglas yang secara matematis dituliskan sebagai berikut:

$$
\begin{aligned}
\mathrm{Y}=\mathrm{aX}_{1}{ }^{\mathrm{b} 1} \mathrm{X}_{2}{ }^{\mathrm{b} 2} \mathrm{X}_{3}{ }^{\mathrm{b} 3} \mathrm{X}_{4}^{\mathrm{b} 4} \mathrm{X}_{5}^{\mathrm{b} 5} \mathrm{e}^{\mathrm{u}} \\
\text { Fungsi produksi Cobb Douglas }
\end{aligned}
$$
dapat diubah menjadi fungsi linier dengan mengubah ke dalam bentuk logaritma natural untuk memudahkan estimasi, sehingga fungsi tersebut berubah menjadi:

$\operatorname{Ln} Y=\operatorname{Ln} a+b_{1} \operatorname{Ln} X_{1}+b_{2} \operatorname{Ln} X_{2}+b_{3}$

$\operatorname{Ln} X_{3}+b_{4} \operatorname{Ln} X_{4}+b_{5} \operatorname{Ln} X_{5}+u$

Dimana:

$\mathrm{Y}=$ Produksi cabai merah besar $(\mathrm{kg})$

$\mathrm{X}_{1}=$ Jumlah tenaga kerja $(\mathrm{HOK})$

$\mathrm{X}_{2}=$ Jumlah benih $(\mathrm{kg})$

$\mathrm{X}_{3}=$ Jumlah pupuk kandang $(\mathrm{kg})$

$\mathrm{X}_{4}=$ Jumlah pupuk kimia $(\mathrm{kg})$

$\mathrm{X}_{5}=$ Jumlah pestisida (liter)

$\mathrm{a}=$ Intersep

$b_{1}-b_{5}=$ koefisien regresi sekaligus elastisitas produksi

$\mathrm{u}=$ error tertentu

Setelah diperoleh fungsi produksi usahatani cabai merah besar kemudian dilakukan pengujian statistik untuk mengetahui faktor produksi apa saja yang berpengaruh terhadap produksi cabai merah besar. Uji statistik terdiri dari koefisien determinasi $\left(\mathrm{R}^{2}\right), \quad$ uji signifikansi simultan (Uji-F), dan uji signifikansi parsial (Uji-t). 
1. Koefisien determinasi $\left(\mathrm{R}^{2}\right)$

Koefisien determinasi

menunjukkan seberapa besar faktor produksi tenaga kerja, benih, pupuk kandang, dan pupuk kimia yang digunakan dalam proses budidaya dapat menjelaskan produksi cabai merah besar.

2. Uji signifikansi simultan (Uji-F)

Uji signifikansi simultan dimaksudkan untuk mengetahui ada atau tidaknya pengaruh seluruh variabel faktor produksi secara bersama-sama terhadap produksi cabai merah besar. Hipotesis dan pengambilan keputusan Uji-F adalah sebagai berikut:

- $\mathrm{H}_{0}: \mathrm{X}_{1}=\mathrm{X}_{2}=\ldots=\mathrm{X}_{\mathrm{n}}=0$; artinya tidak ada satupun faktor produksi yang berpengaruh signifikan.

- $\mathrm{H}_{1}$ : paling tidak ada satu $\mathrm{X}_{\mathrm{i}} \neq 0$; artinya minimal ada satu faktor produksi yang berpengaruh nyata.

- P-value uji $\mathrm{F}>\alpha$, maka terima $\mathrm{H}_{0}$, artinya faktor produksi secara bersama-sama tidak berpengaruh signifikan terhadap produksi cabai merah besar.

- P-value uji $\mathrm{F}<\alpha$, maka tolak $\mathrm{H}_{0}$, artinya faktor produksi secara bersama-sama berpengaruh signifikan terhadap produksi cabai.
3. Uji Signifikansi Parsial (Uji-t)

Uji-t dilakukan untuk melihat pengaruh setiap variabel faktor produksi terhadap produksi cabai merah besar. Hipotesis dan pengambilan keputusan Uji-t adalah sebagai berikut:

- $\mathrm{H}_{0}: \mathrm{X}_{\mathrm{i}}=0$; artinya suatu variabel faktor produksi tidak memiliki pengaruh nyata terhadap produksi cabai merah besar.

- $\mathrm{H}_{1}: \mathrm{X}_{\mathrm{i}}>0$; artinya suatu variabel faktor produksi memiliki pengaruh nyata terhadap produksi cabai merah besar.

- P-value uji $\mathrm{t}>\alpha$, maka terima $\mathrm{H}_{0}$, artinya suatu faktor produksi tidak berpengaruh nyata terhadap produksi cabai.

- P-value uji $\mathrm{t}<\alpha$, maka tolak $\mathrm{H}_{0}$, artinya suatu faktor produksi berpengaruh nyata terhadap produksi cabai.

Untuk mengetahui efisiensi penggunaan faktor produksi pada usahatani cabai merah besar dilakukan analisis efisiensi alokatif dengan menghitung perbandingan antara nilai produk marjinal (NPM) dengan biaya korbanan marjinal (BKM). Efisiensi alokatif tercapai apabila NPM/BKM sama dengan 1. Persamaan tersebut dapat 
ditulis sebagai berikut (Soekartawi, 2003):

$\frac{\mathrm{NPM}}{\mathrm{BKM}}=1 \quad$ atau $\quad \frac{\text { b.Y.P }}{\mathrm{X}_{\mathrm{P}} \mathrm{P}_{\mathrm{x}}}=1$

Dimana:

$\mathrm{b}=$ elastisitas produksi

$\mathrm{Y}=$ produksi cabai merah besar

$\mathrm{P}_{\mathrm{y}}=$ harga cabai merah besar

$\mathrm{X}=$ penggunaan faktor produksi

$\mathrm{P}_{\mathrm{x}}=$ harga faktor produksi

Hasil perbandingan NPM dengan BKM dapat menemui kondisi sebagai berikut:

NPM/BKM > 1 ; artinya faktor produksi

(X) belum efisien sehingga perlu ditambah.

NPM/BKM $<1$; artinya faktor produksi

(X) tidak efisien sehingga perlu dikurangi.

\section{HASIL DAN PEMBAHASAN}

\section{Karakteristik Responden}

Sebanyak 36 orang petani cabai merah besar di Desa Sukalaksana berada pada usia kerja produktif, sedangkan 4 orang sisanya berada di usia kerja kurang produktif. Kelompok umur dengan persentase tertinggi adalah 31-40 tahun yaitu sebesar 30\%. Banyaknya petani dengan usia kerja produktif menunjukkan bahwa usahatani cabai merah besar di
Desa Sukalaksana masih dapat diusahakan dengan baik.

Ditinjau dari tingkat pendidikan, sebagian besar petani di Desa Sukalaksana adalah lulusan Sekolah Dasar (SD) yaitu sebanyak 24 orang (60 \%). Petani yang berpendidikan SMP sebanyak 8 orang, petani yang berpendidikan SMA sebanyak 7 orang, dan petani yang berpendidikan tinggi hanya 1 orang. Hal tersebut menunjukkan bahwa tingkat pendidikan petani di Desa Sukalaksana masih tergolong rendah.

Rata-rata luas lahan petani cabai di Desa Sukalaksana adalah 0,315 ha. Sebanyak 35 orang petani $(87,5 \%)$ memiliki luas lahan yang kurang dari 0,5 ha, sedangkan 5 lainnya berusahatani di lahan lebih dari 0,5 ha. Kondisi tersebut menunjukkan bahwa sebagian besar petani cabai di Desa Sukalaksana merupakan petani gurem dengan tingkat penguasaan lahan dibawah 0,5 ha.

Status penguasaan lahan di Desa Sukalaksana terbagi menjadi tiga, yaitu pemilik lahan, penyewa, dan penggarap. Persentase petani pemilik paling tinggi dibandingkan persentase petani penyewa dan petani penggarap. Persentase petani pemilik yaitu sebesar 47,5\%, petani penyewa sebesar $42,5 \%$ dan petani penggarap sebesar $10 \%$. Hal tersebut 
menunjukkan bahwa mayoritas petani cabai merah besar di Desa Sukalaksana berstatus sebagai pemilik lahan.

Pengalaman berusahatani dapat mempengaruhi perilaku dan kemampuan petani dalam berusahatani. Semakin lama pengalaman, maka semakin banyak pelajaran dan ilmu yang didapatkan. Sebagian besar petani cabai merah besar di Desa Sukalaksana sudah berusahatani cabai merah besar selama 11-20 tahun, dengan persentase sebesar $62,5 \%$. Petani dengan pengalaman usahatani 11-20 tahun merupakan petani mandiri yang sudah mampu mengelola usahatani cabai sendiri dan menanggung seluruh risiko usahatani cabai.

\section{Fungsi Produksi Usahatani Cabai Merah Besar}

Model analisis yang digunakan untuk mengestimasi fungsi produksi usahatani cabai merah besar adalah fungsi produksi Cobb Douglas. Faktorfaktor produksi yang diestimasi ke dalam model meliputi tenaga kerja $\left(\mathrm{X}_{1}\right)$, benih $\left(\mathrm{X}_{2}\right)$, pupuk kandang $\left(\mathrm{X}_{3}\right)$, pupuk kimia $\left(\mathrm{X}_{4}\right)$, dan pestisida $\left(\mathrm{X}_{5}\right)$ berdasarkan penggunaan setiap petani. Fungsi produksi Cobb Douglas diubah ke dalam bentuk persamaan logaritma natural sehingga menjadi persamaan regresi linier berganda. Hasil analisis regresi linier berganda pada fungsi produksi usahatani cabai merah besar adalah sebagai berikut :

Tabel 2. Hasil Uji Regresi

\begin{tabular}{|c|c|c|c|}
\hline Variabel & $\begin{array}{l}\text { Koefisien } \\
\text { Regresi }\end{array}$ & $\mathrm{t}$ hitung & Sig \\
\hline $\begin{array}{l}\text { Tenaga } \\
\text { kerja }\end{array}$ & 0,418 & 2,811 & $0,008^{*}$ \\
\hline Benih & 0,255 & 2,620 & $0,013^{*}$ \\
\hline $\begin{array}{l}\text { Pupuk } \\
\text { kandang }\end{array}$ & $-0,006$ & $-0,124$ & 0,902 \\
\hline $\begin{array}{l}\text { Pupuk } \\
\text { kimia }\end{array}$ & 0,394 & 3,638 & $0,001^{*}$ \\
\hline Pestisida & $-0,072$ & $-0,677$ & 0,503 \\
\hline \multicolumn{4}{|c|}{$\begin{array}{ll}\text { F Hitung }=46,359 & \text { sig }=0,000^{*} \quad \text { RTS }=0,989 \\
\text { R square }=0,872 & \text { Adj. R square }=0,853\end{array}$} \\
\hline $\begin{array}{l}\text { Keterang } \\
*=\text { berp }\end{array}$ & aruh sign & & \\
\hline
\end{tabular}

Berdasarkan hasil uji regresi pada

Tabel 2, maka fungsi produksi usahatani cabai merah besar di Desa Sukalaksana dapat dituliskan sebagai berikut:

$\operatorname{LnY}=3,308+0,418 \operatorname{LnX}_{1}+0,255 \operatorname{LnX}_{2}-$ $0,006 \operatorname{LnX}_{3}+0,394 \operatorname{LnX}_{4}-0,072 \operatorname{LnX}_{5}$

Jika dituliskan ke dalam bentuk fungsi produksi Cobb Douglas adalah sebagai berikut:

$\mathrm{Y}=3,308 \mathrm{X}_{1}{ }^{0,418} \mathrm{X}_{2}{ }^{0,255} \mathrm{X}_{3}{ }^{-0,006} \mathrm{X}_{4}{ }^{0,394} \mathrm{X}_{5}{ }^{-0,072}$

- Nilai intersep (a) sebesar 3,308 menunjukkan bahwa usahatani cabai tanpa penggunaan tenaga kerja, benih, pupuk kandang, pupuk kimia, dan pestisida akan menghasilkan produksi cabai (Y) sebesar 2,433.

- Elastisitas produksi tenaga kerja $\left(\mathrm{X}_{1}\right)$ memiliki nilai sebesar 0,418. Hal tersebut menunjukkan bahwa setiap peningkatan tenaga kerja 1 satuan, 
maka akan meningkatkan produksi cabai sebesar 0,418 satuan dengan asumsi faktor produksi lainnya tetap.

- Elastisitas produksi benih $\left(\mathrm{X}_{2}\right)$ memiliki nilai sebesar 0,255 . Hal tersebut menunjukkan bahwa setiap peningkatan 1 satuan benih, maka akan meningkatkan produksi cabai sebesar 0,255 satuan dengan asumsi faktor produksi lainnya tetap.

- Elastisitas produksi pupuk kandang $\left(\mathrm{X}_{3}\right)$ memiliki nilai sebesar (-) 0,006. Hal tersebut menunjukkan bahwa setiap peningkatan 1 satuan pupuk kandang, maka akan mengurangi produksi cabai sebesar 0,006 satuan dengan asumsi faktor produksi lainnya tetap.

- Elastisitas produksi pupuk kimia $\left(\mathrm{X}_{4}\right)$ memiliki nilai sebesar 0,394. Hal tersebut menunjukkan bahwa setiap peningkatan 1 satuan pupuk kimia, maka akan meningkatkan produksi cabai sebesar 0,394 satuan dengan asumsi faktor produksi lainnya tetap.

- Elastisitas produksi pestisida (X) memiliki nilai sebesar (-) 0,072. Hal tersebut menunjukkan bahwa setiap peningkatan 1 satuan pestisida, maka akan menurunkan produksi cabai sebesar 0,072 satuan.
Penjumlahan koefisien regresi seluruh variabel faktor produksi dapat menentukan return to scale atau skala usaha. Hasil penjumlahan koefisien regresi seluruh variabel faktor produksi adalah sebesar $0,989(0,989<1)$. Hal tersebut menunjukkan bahwa skala usahatani cabai merah besar di Desa Sukalaksana berada pada tahap decreasing return to scale yang berarti proporsi penambahan faktor produksi melebihi proporsi penambahan produksi. Pada tahap ini apabila faktor produksi ditambah maka tambahan produksi yang dihasilkan akan semakin berkurang.

\section{Uji Statistik}

\section{a. Koefisien Determinasi}

Koefisien determinasi ditunjukkan oleh nilai Adj. R square pada Tabel 2. Nilai Adj. R square penelitian ini adalah sebesar 0,853 yang artinya 85,3 persen produksi cabai merah besar di Desa Sukalaksana dapat dijelaskan oleh penggunaan faktor produksi tenaga kerja, benih, pupuk kandang, pupuk kimia, dan pestisida, sedangkan 14,7 persen sisanya dijelaskan oleh faktor lain yang tidak digunakan dalam penelitian ini.

b. Uji-F

Uji-F dilakukan pada $\alpha=5 \%$ dengan nilai $F_{\text {tabel }}$ sebesar 2,49. Berdasarkan hasil uji $\mathrm{F}$ pada Tabel 2, 
diperoleh $\mathrm{F}_{\text {hitung }}=46,359$ dan $\operatorname{sig}=$ 0,000. Karena $F_{\text {hitung }}$ lebih besar dari $F_{\text {tabel }}$ dan signifikansi lebih kecil dari 0,05 maka $\mathrm{H}_{0}$ uji $\mathrm{F}$ ditolak, artinya faktor produksi secara bersama-sama berpengaruh nyata terhadap produksi cabai. Hasil uji $\mathrm{F}$ tersebut menunjukkan bahwa pada usahatani cabai merah besar di Desa Sukalaksana, penggunaan tenaga kerja, benih, pupuk kandang, pupuk kimia, dan pestisida secara bersama-sama dapat mempengaruhi produksi cabai merah besar.

c. Uji-t

Uji-t dilakukan pada alfa $5 \%$ dengan uji dua sisi, tabel yang diperoleh adalah sebesar 2,032. Hasil pengujian signifikansi parsial pada penelitian ini dapat dilihat dalam Tabel 2 dengan penjelasan sebagai berikut :

- Tenaga Kerja

Berdasarkan hasil uji-t pada Tabel 2 diperoleh nilai $t_{\text {hitung }}$ variabel tenaga kerja lebih besar dari tabel $(2,811>2,032)$ dan nilai signifikansi lebih kecil dari alfa $(0,008<0,05)$. Hal tersebut menunjukkan bahwa tenaga kerja berpengaruh positif dan signifikan terhadap produksi cabai. Menurut Soekartawi (2003) tenaga kerja merupakan faktor produksi yang penting dan perlu diperhitungkan dalam proses produksi. Peningkatan jumlah tenaga kerja akan dapat memberikan peningkatan hasil dalam proses produksi. Pernyataan tersebut didukung oleh hasil penelitian Dewi dan Yuliarmi (2017) yang menunjukkan bahwa faktor produksi tenaga kerja merupakan faktor produksi yang berpengaruh signifikan dalam menentukan tingkat produksi kopi arabika. Penelitian yang dilakukan oleh Mewalili dan Rauf (2011) juga memperoleh hasil bahwa jumlah produksi Jagung dipengaruhi oleh tenaga kerja yang digunakan dalam proses produksi.

Tenaga kerja pada usahatani cabai merah besar di Desa Sukalaksana terdiri dari tenaga kerja dalam dan luar keluarga dengan rata-rata penggunaan 503,5 HOK/ha. Upah buruh tani di Desa Sukalaksana yaitu Rp 50.000 untuk lakilaki, dan $\mathrm{Rp} 35.000$ untuk perempuan di mana upah tersebut cukup tinggi jika dibandingkan dengan desa lain. Kegiatan budidaya cabai memerlukan banyak tenaga kerja terutama pada proses pengolahan lahan dan pemeliharaan. Cabai memerlukan pemeliharaan yang intensif agar tanaman sehat dan dapat dipanen hingga berkali-kali. Pemeliharaan tersebut memerlukan banyak tenaga kerja, oleh karena itu tenaga kerja dapat mempengaruhi produksi cabai. Jika tenaga kerja 
melakukan pemeliharaan cabai dengan benar maka penggunaan tenaga kerja dapat meningkatkan produksi cabai, sedangkan jika pemeliharaan tidak dilakukan dengan benar maka tenaga kerja hanya akan meningkatkan biaya produksi.

- Benih

Berdasarkan hasil uji-t pada Tabel 2 diperoleh nilai $t_{\text {hitung }}$ variabel benih lebih besar dari tabel $(2,620>2,032)$ dan nilai signifikansi lebih kecil dari alfa $(0,013<0,05)$. Hal tersebut menunjukkan bahwa variabel benih berpengaruh positif dan signifikan terhadap produksi cabai. Hal tersebut didukung oleh hasil penelitian Benu Olfie Suzana, dkk (2011) dan Nurul Risti Mutiarasari, dkk (2019) yang menyatakan bahwa benih berpengaruh secara signifikan tarhadap jumlah produksi.

Benih yang digunakan dalam usahatani cabai merah besar di Desa Sukalaksana adalah benih cabai merah besar varietas victor dengan rata-rata penggunaan $0,2 \mathrm{~kg} / \mathrm{ha}$ dan harga per kemasan 10 gram adalah Rp 117.000. Varietas victor merupakan cabai merah besar hibrida yang beradaptasi dengan baik di dataran sedang dengan ketinggian 400-700 mdpl sehingga cocok dibudidayakan di Desa Sukalaksana.
Cabai merah besar varietas Victor memiliki beberapa keunggulan diantaranya produktivitas tinggi (14 ton/ha), permukaan buah halus dan berwarna cerah, serta memiliki rasa yang pedas.

\section{- Pupuk Kimia}

Berdasarkan hasil uji-t pada Tabel 2 diperoleh nilai thitung variabel pupuk kimia lebih besar dari $t_{\text {tabel }}(3,638>$ 2,032) dan nilai signifikansi lebih kecil dari alfa $(0,001<0,05)$. Hal tersebut menunjukkan bahwa pupuk kimia berpengaruh positif dan signifikan terhadap produksi cabai merah besar. Hal tersebut sesuai dengan hasil penelitian Anjarwati (2013) yang menyatakan bahwa penggunaan pupuk kimia dapat meningkatkan produksi cabai merah. Penelitian Susanti (2018) juga menunjukkan bahwa pupuk kimia dapat mempengaruhi produksi bawang merah.

Rata-rata penggunaan pupuk kimia pada usahatani cabai di Desa Sukalaksana adalah $1.711,43 \mathrm{~kg} / \mathrm{ha}$ yang terdiri dari pupuk NPK 677,78 kg/ha, pupuk TSP $566,67 \mathrm{~kg} / \mathrm{ha}$, dan pupuk ZA 466,98 $\mathrm{kg} / \mathrm{ha}$. Tanaman cabai memerlukan unsur hara yang cukup terutama pada fase pembungaan dan pembuahan sehingga dosis pupuk biasanya ditambah pada fase-fase tersebut. Kebutuhan unsur hara 
yang tercukupi dapat meningkatkan produksi cabai.

- Pupuk Kandang

Berdasarkan hasil uji-t pada Tabel 2 diperoleh nilai $t_{\text {hitung }}$ variabel pupuk kandang lebih kecil dari tabel $(-0,124<$ 2,032) dan nilai signifikansi lebih besar dari alfa $(0,902>0,05)$. Hal tersebut menunjukkan bahwa variabel pupuk kandang tidak signifikan terhadap produksi cabai. Petani cabai di Desa Sukalaksana menggunakan pupuk kotoran ayam sebagai pupuk kandang. Rata-rata penggunaan pupuk kandang pada usahatani cabai merah besar di Desa Sukalaksana adalah 21 ton/ha.

- Pestisida

Berdasarkan hasil uji-t pada Tabel 2 diperoleh nilai $t_{\text {hitung }}$ variabel pestisida lebih kecil dari tabel $(-0,677<2,032)$ dan nilai signifikansi lebih besar dari alfa $(0,503>0,05)$. Hal tersebut menunjukkan bahwa variabel pestisida tidak signifikan terhadap produksi cabai. Rata-rata penggunaan pestisida pada usahatani cabai merah besar di Desa Sukalaksana adalah 7,5 lt/ha.

\section{Efisiensi Alokatif Usahatani Cabai merah besar di Desa Sukalaksana}

Proses produksi secara alokatif dikatakan efisien jika nilai perbandingan NPM dan BKM sama dengan satu untuk masing-masing faktor produksi yang digunakan. Faktor produksi yang dianalisis efisiensinya adalah faktor produksi yang berpengaruh signifikan terhadap produksi cabai, yaitu tenaga kerja, benih, dan pupuk kimia. Hasil analisis efisiensi alokatif adalah sebagai berikut:

Tabel 3. Hasil Perhitungan Efisiensi Alokatif Usahatani Cabai Merah Besar

\begin{tabular}{|c|c|c|c|}
\hline $\begin{array}{c}\text { Faktor } \\
\text { Produksi }\end{array}$ & NPM & BKM & NPM/BKM \\
\hline $\begin{array}{c}\text { Tenaga } \\
\text { kerja } \\
(\mathrm{HOK} / \mathrm{ha})\end{array}$ & 56816,62 & 50875 & 1,12 \\
\hline $\begin{array}{l}\text { Benih } \\
\text { (g/ha) } \\
\text { Pupuk }\end{array}$ & 88981,58 & 11700 & 7,60 \\
\hline $\begin{array}{c}\text { NPK } \\
(\mathrm{kg} / \mathrm{ha})\end{array}$ & 15747,94 & 16370 & 0,962 \\
\hline
\end{tabular}

- Tenaga Kerja

Berdasarkan Tabel 3, faktor produksi tenaga kerja memiliki NPM sebesar 56.816,62 yang artinya penambahan 1 HOK tenaga kerja akan meningkatkan pendapatan $\mathrm{Rp} 56.816,62$ dengan biaya tambahan yang dikeluarkan yaitu sebesar Rp 50.875. Nilai NPM/BKM faktor produksi tenaga kerja lebih dari satu yang menunjukkan bahwa penggunaan faktor produksi tenaga kerja belum efisien, artinya penggunaan tenaga kerja dalam usahatani cabai masih berpotensi untuk menghasilkan pendapatan usahatani yang lebih besar sehingga jumlah tenaga kerja perlu ditambah. 
Rata-rata penggunaan tenaga kerja dalam usahatani cabai merah besar di Desa Sukalaksana adalah 503 HOK/ha. Penambahan tenaga kerja perlu dilakukan karena usahatani cabai memerlukan banyak tenaga kerja terutama untuk pemeliharaan tanaman cabai.

- Benih

Berdasarkan Tabel 3, faktor produksi benih memiliki NPM sebesar 88.981,58 yang artinya penambahan 1 gram benih akan meningkatkan pendapatan $\mathrm{Rp} 88.981,58$ dengan biaya yang dikeluarkan untuk penambahan 1 gram benih yaitu sebesar $\mathrm{Rp} 11.700$. Nilai NPM/BKM faktor produksi benih lebih dari satu yang menunjukkan bahwa penggunaan faktor produksi benih belum efisien, artinya penggunaan benih dalam usahatani cabai masih berpotensi untuk menghasilkan pendapatan usahatani yang lebih besar sehingga jumlah benih perlu ditambah.

Rata-rata penggunaan benih pada usahatani cabai merah besar di Desa Sukalaksana adalah 196 gr/ha, sedangkan kebutuhan benih cabai per hektar menurut Arianto (2010) adalah 150-300 gr/ha. Penambahan benih perlu dilakukan untuk mendapatkan bahan tanam yang lebih banyak, akan tetapi penambahan benih yang terlalu banyak pada lahan yang terbatas dapat meningkatkan kompetisi antar tanaman dan tidak baik untuk pertumbuhan tanaman cabai.

- Pupuk Kimia

Berdasarkan Tabel 3, faktor produksi pupuk kimia memiliki NPM sebesar 15.747,94 yang artinya penambahan $1 \mathrm{~kg}$ pupuk kimia akan meningkatkan pendapatan Rp 15.747,94 dengan biaya yang dikeluarkan untuk penambahan $1 \mathrm{~kg}$ pupuk kimia adalah sebesar Rp 16.370. Nilai NPM/BKM faktor produksi pupuk kimia kurang dari satu yang menunjukkan bahwa penggunaan faktor produksi benih tidak efisien, artinya biaya yang dikeluarkan untuk pupuk kimia lebih besar dari tambahan pendapatan yang diperoleh sehingga jumlahnya perlu dikurangi agar biayanya tidak terlalu tinggi.

Rata-rata penggunaan pupuk kimia pada usahatani cabai merah besar di Desa Sukalaksana adalah $1.711 \mathrm{~kg} / \mathrm{ha}$, sedangkan anjuran kebutuhan pupuk kimia per hektar pada usahatani cabai menurut Wardani (2008) adalah 1.000$1.500 \mathrm{~kg} / \mathrm{ha}$. Dengan demikian penggunaan pupuk kimia pada usahatani cabai di Desa Sukalaksana sudah melebihi anjuran. 


\section{KESIMPULAN DAN SARAN}

Faktor produksi yang berpengaruh signifikan terhadap produksi cabai merah besar di Desa Sukalaksana yaitu tenaga kerja, benih, dan pupuk kimia, sedangkan faktor produksi pupuk kandang dan pestisida tidak memberikan pengaruh yang signifikan terhadap produksi cabai merah besar. Penggunaan faktor produksi tenaga kerja dan benih pada usahatani cabai merah besar belum efisien karena nilai NPM/BKM lebih besar dari satu sehingga penggunaan tenaga kerja dan benih perlu ditambah, sedangkan penggunaan pupuk kimia tidak efisien karena nilai NPM/BKM lebih kecil dari satu sehingga penggunaan pupuk kimia perlu dikurangi.

Untuk meningkatkan produksi cabai merah besar, petani perlu memperhatikan penggunaan tenaga kerja, benih, dan pupuk kimia. Selain itu petani perlu membatasi penggunaan pupuk kandang dan pestisida karena dapat mengurangi produksi. Untuk mengoptimalkan penggunaan faktorfaktor produksi usahatani cabai merah besar agar efisien maka penggunaan tenaga kerja dan benih perlu ditambah, sedangkan penggunaan pupuk kimia perlu dikurangi.

\section{DAFTAR PUSTAKA}

Arifah Anjarwati, Eni Istiyanti dan Uswatun Hasanah (2013). Efisiensi Penggunaan Faktor Produksi Pada Usahatani Cabai merah besar (Capsicum spp.) di Lahan Pasir Pantai Kecamatan Temon Kabupaten Kulon Progo. Jurnal Surya Agritama, 2(1): 11-20.

Ida Ayu Nyoman Utami Dewi dan Ni Nyoman Yuliarmi. (2017). Pengaruh Modal, Tenaga Kerja, dan Luas Lahan Terhadap Jumlah Produksi Kopi Arabika di Kecamatan Kintamanai Kabupaten Bangli. Jurnal Ekonomi Pembangunan Unud, 6(6): 11271156.

Hasan Mustofa. (2000). Teknik Sampling. Universitas Parahyangan, Bandung.

Famly Mewalili dan Rustam Abd. Rauf. (2014). Analisis Efisiensi Penggunaan Faktor Produksi Usahatani Jagung di Desa Bulupountu Jaya Kecamatan Sigi Biromaru. Jurnal Agrotekbis, 2(5): 526-532.

Nurul Risti Mutiarasari, Anna Fariyanti dan Netti Tinaprilla (2019). Efisiensi Alokatif Input Faktor Pada Usahatani Bawang Merah (Allium ascolonicum L) di Majalengka, Jawa Barat. Jurnal Sosiohumaniora, 21(2): 216 - 221

Wiwit Rahayu. dan Erlyna, W.R. (2010). Analisis Efisiensi Ekonomi Penggunaan Faktor-faktor Produksi pada Usahatani Kedelai Kabupaten Sukoharjo. Jurnal Caraka Tani, XXV(1): 119-125

Soekartawi. (1995). Analisis Usahatani. UI Press, Jakarta.

Soekartawi. (2003). Agribisnis Teori dan Aplikasinya. PT Raja Grafindo, Jakarta.

H. Susanti, K. Budiraharjo dan M. Handayani. (2018). Analisis Pengaruh Faktor-faktor Produksi 
Terhadap Produksi Usahatani Bawang Merah di Kecamatan Wanasari Kabupaten Brebes. Jurnal Sosial Ekonomi Pertanian, 2 (1) : 23-30.

Benu, Olfie L.S., Joachim, N.K.D., dan Sudarti. 2011). Analisis Efisiensi Penggunaan Faktor Produksi pada Usahatani Padi Sawah di Desa Mopuya Utara. Jurnal ASE, 7 (1) : 38-47.
Tuti Karyani, E.Renaldy, Agriani Hermita dan Hesty Nurul Utami (2015). Design of Supply Chain Financing Model of Red Chili Commodity With Structured Market Orientation. Ijaber, 13(7): 6187-6200

Nila Wardani dan Jamhari H.P. (2008). Teknologi Budidaya Cabai Merah besar. Badan Penelitian dan Pengembangan Pertanian, Bogor. 